\title{
Mushroom Diversity of the Gandhi Krishi Vigyana Kendra (GKVK) Campus, University of Agricultural Sciences, Bangalore, Karnataka (India)
}

\author{
M.C. Sandhya, K.N. Prabhu and N. Earanna* \\ Department of Biotechnology, University of Agricultural Sciences, GKVK campus, \\ Bangalore-560065, India \\ *Corresponding author
}

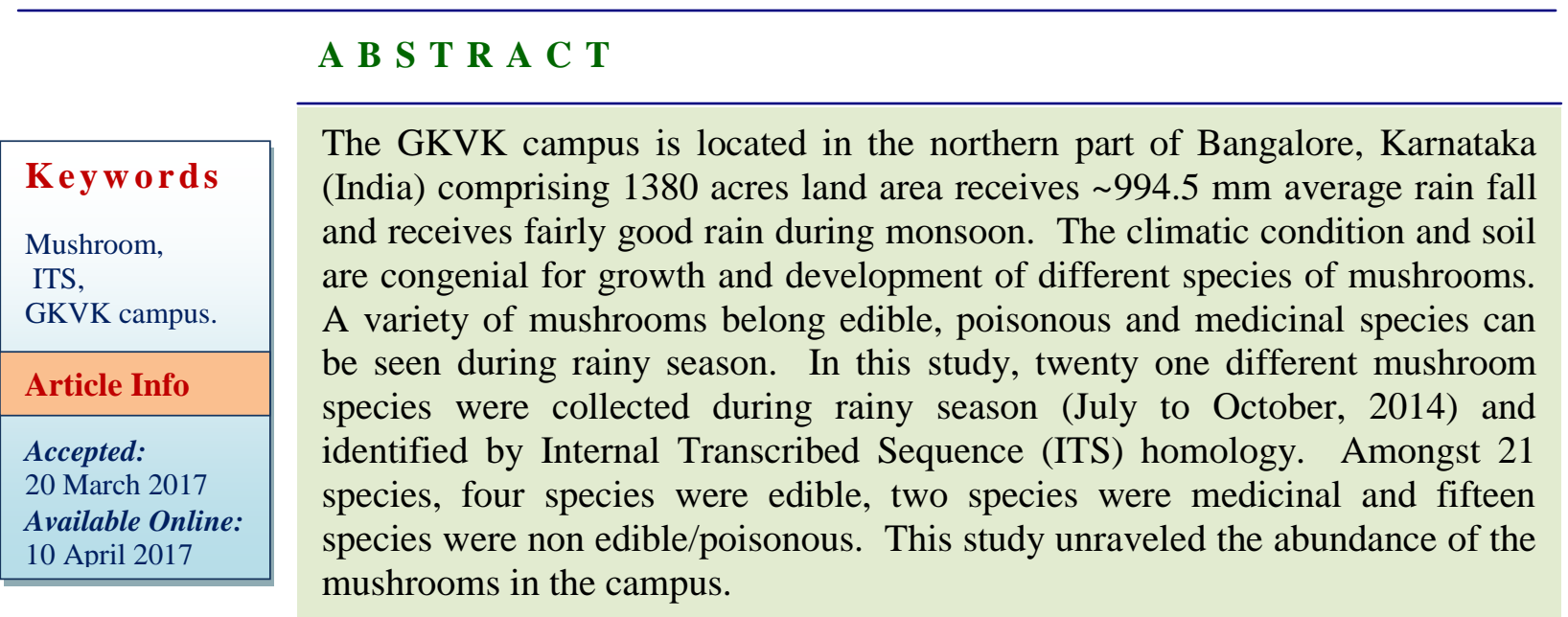

\section{Introduction}

Mushroom growing wild are picked up and eaten by mankind from time immemorial. The ancient Romans regarded mushrooms as "Food of the Gods"; the Egyptians considered as "a gift from the God Osiris"; while the Chinese viewed them as "the elixir of life". Thus, mushrooms were famed due to their taste, delicacy, flavour and nutritional quality. There are about 69 thousand known mushroom species of which 2000 species are regarded as prime edible mushrooms. But, a few species are being cultivated commercially around the world (Chang and miles, 2004). Mushrooms can grow in almost all types of soil, on decaying organic matter, wood stumps, termite nests etc. Majority of mushrooms are saprophytes and some are associated with plant roots which are referred to as mycorrhizal mushrooms (Hall et al., 2003). Mushrooms emanate well at relative humidity levels around 95-100\%, and substrate moisture levels at 50 to $75 \%$ (Mahajan et al., 2008). Since, mushrooms are ephemeral in nature; their documentation needs constant survey and collection during appropriate seasons. The life cycle of mushroom starts with germination of spore that produces a primary mycelium. This mycelium continues to grow in branches and forms mycelial network. When two sexually complementary hyphal network intercepts one another and make contact, the resulting mycelium formed is dikaryotic (Brown and 
Casselton, 2001). This mycelium is fertile and capable of producing fruit bodies.

Characterization of mushroom species requires basic knowledge on the structure of the fungi. The Phenotypic characters used for identification of mushroom species are shape, size, texture, colour and odour of the fruiting body (Aroroa, 1986). However, in recent years, molecular tools well supported the mushroom taxonomy. Molecular markers, particularly DNA based techniques are quick and reliable to establish identities of wild mushrooms. The Internal Transcribed Spacer (ITS) region/ $18 \mathrm{~S}$ rRNA gene sequence are the most widely used techniques in molecular phylogenetics of mushroom as these sequences are conserved irrespective of life history and evolution (Rajaratnam and Thiagarajan, 2012).

The GKVK Campus of the University of Agricultural sciences (UAS), Bangalore covering 1380 acres land area is located in the Northern part of Bangalore between Latitude; $13^{\circ} 05^{\prime}$ North and Longitude: $77^{\circ}$ 34' East and Altitude: $924 \mathrm{~m}$ (above mean sea level). The maximum and minimum temperature was about 29.6 and $18.5{ }^{\circ} \mathrm{C}$ respectively. The GKVK campus is considered as one of the greenest areas in Bangalore. As the campus spread in the large area which harbors many kinds of the mushrooms species, it is important to explore the diversity of the mushrooms. Therefore, we intended to unravel the mushroom diversity of the campus during rainy season during the year 2014.

\section{Materials and Methods}

\section{Collection of mushrooms}

Mushroom hunting was started from July 2014. Mushrooms were collected in paper bags as and when appeared during rainy season till the end of October 2014. While collecting the mushroom fruit body's field characters were recorded. Then the samples were labeled as GKVK-1 to GKVK-21.

\section{DNA extraction and amplification}

The genomic DNA from the cap tissue of the mushroom fungus was extracted by modified Cetyl Trimethyl Ammonium Bromide (CTAB) lysis method (Doyle and Doyle, 1987). Dried tissue $(0.2 \mathrm{~g})$ of the mushroom sample was ground into fine powder using liquid nitrogen and transferred into extraction buffer containing $\mathrm{CTAB}$ and incubated at 65 ${ }^{\circ} \mathrm{C}$ for 45 minutes. After incubation the tubes were centrifuged at $10,000 \mathrm{rpm}$ for 10 minutes. The clear supernatant was transferred into a fresh centrifuge tube and equal volume of chloroform; Iso-amyl alcohol $(24: 1 \mathrm{~V} / \mathrm{V})$ was added and mixed by inverting the tubes. These tubes were centrifuged at $10000 \mathrm{rpm}$ for 10 minutes. The DNA was precipitated by adding 0.6 volumes of chilled Isopropanol and centrifuged after 20 minutes. The pellet was washed with $70 \%$ ethanol, air dried and dissolved in Tris-EDTA (10:1) buffer. The DNA thus extracted was checked for purity as well as concentration using Nano drop (Eppendorf).

The DNA was PCR amplified in a $40 \mu \mathrm{l}$ reaction mixture containing $4.0 \mu \mathrm{l}$ of $10 \mathrm{X}$ PCR Taq. buffer, $4.0 \mu \mathrm{l}$ of $10 \mathrm{mM}$ dNTP's mix, $2.0 \mu \mathrm{l}$ of ITS primers, $0.6 \mu \mathrm{l}$ of Taq. DNA Polymerase, $2.0 \mu \mathrm{l}$ of template DNA, $27.4 \mu \mathrm{l}$ of sterile distilled water. The PCR was carried out in a Thermal Cycler (Astec PC818) programmed as follows: initial denaturation at $96{ }^{\circ} \mathrm{C}$ for $3 \mathrm{~min}, 38$ cycles of denaturation of $94{ }^{\circ} \mathrm{C}$ for $1 \mathrm{~min}$, annealing at $60{ }^{\circ} \mathrm{C}$ for $30 \mathrm{sec}$ and extension at $72{ }^{\circ} \mathrm{C}$ for 1 min and final extension at $72{ }^{\circ} \mathrm{C}$ for $10 \mathrm{~min}$. The amplified products were separated by agarose gel $(0.8 \%)$ electrophoresis. The amplified product was eluted from the 
agarose gel using gel extraction kit (Gene JET $^{\mathrm{TM}}$ Gel Extraction Kit, Thermo Scientific) and the eluted DNA was got sequenced by Scigenom Labs Pvt. Ltd, India using ITS1 and ITS4 primers.

\section{Sequence analysis and homology search}

Sequence results were analyzed with online software of National Centre for Biotech and phylogenetic analyses were performed to know the relationship between identified and mushroom with its sequence data available in NCBI. Preliminary pair wise and multiple alignments were performed using Clustal-W for all twenty mushroom sequence data independently.

\section{Results and Discussion}

Mushrooms are the objects of much curiosity, speculation since time immemorial and also one of the most important components of the ecosystem. Their edibility, poisonous nature psychotropic properties, medicinal properties draw the attention of the researchers. In the present study, 21 different mushroom species (Fig. 2) were collected and identified. Out of 21 mushrooms collected, 20 (GKVK-1-20) were identified using ITS region sequence homology (http://www.ncbi.nlm.nih.gov). The figure representing BLAST search homology for the mushroom GKVK-1 is provided in figure 1. Whereas, figures for BLAST search homology of the other mushrooms designated as GKVK2 to GKVK20 are provided in supplementary data for reference.

The ITS sequence of the GKVK-1 (707bp) showed 100\% homology with Macrolepiota globosa, GKVK-2(613bp) showed $87 \%$ sequence homology with Ganoderma australe, GKVK-3(639bp) showed 100\% sequence homology with Lepista sp., GKVK4(716bp) showed 99\% sequence homology with Phlebopus portentosus, GKVK-5(644bp) showed $97 \%$ sequence homology with Termitomyces sp., GKVK-6(627bp) showed 99\% sequence homology with Agrocybe pediades, GKVK-7(687bp) showed 94\% sequence homology with Leucoagaricus crystallifer, GKVK-8(647bp) showed 89\% sequence homology for Podoscypha petalodes, GKVK-9(677bp) showed 99\% sequence homology with Agaricus sp., GKVK-10(660bp) showed $87 \%$ sequence homology with Tricholoma giganteum, GKVK-11(661bp) showed 99\% sequence homology with Coprinellus disseminates, GKVK-12(661bp) showed $89 \%$ sequence homology with Ompholotus olivascens, GKVK-13( 706bp) showed 99\% sequence homology with Agaricus sp., GKVK14(692bp) showed 99\% sequence homology with Macrolepiota dolochula, GKVK15(585bp) showed 94\% sequence homology with Panus conchatus, GKVK-16(299bp) showed 97\%sequence homology with Marasmius leveilleanus, GKVK-17(576bp) showed 94\% sequence homology with Polyporus arcularius, GKVK-18(659bp) showed $94 \%$ sequence homology with Lepiota fuscovinacea, GKVK-19(649bp) showed $99 \%$ sequence homology with Agrocybe semiorbicularis and GKVK20(715bp) showed 95\% sequence homology with Marasmius sp.

The mushroom fruiting body of GKVK-21 was identified based on its morphological characters. Pileus of this mushroom was reddish brown in colour, kidney shaped and the border surrounded by white tissue. Stipe was brown in colour, off centric and tapered upward. Texture of the fruiting body was corky and tough. These characters perfectly matched with Ganoderma lucidum when consulted the book entitled Indian polyporaceae (Bakshi, 1971). Thus, the mushroom was confirmed as G. lucidum. 
Table.1 Field information and phenotypic character of mushrooms recorded during collection

\begin{tabular}{|c|c|c|c|c|c|c|c|c|}
\hline \multirow{2}{*}{$\begin{array}{l}\text { Designated } \\
\text { samples }\end{array}$} & \multirow{2}{*}{ Habitat } & \multicolumn{2}{|c|}{ Character of Pileus } & \multirow{2}{*}{$\begin{array}{c}\text { Character } \\
\text { of Gills }\end{array}$} & \multirow[t]{2}{*}{ Annuals } & \multirow[t]{2}{*}{ Character of Stipe } & \multirow{2}{*}{$\begin{array}{c}\text { Name of identified } \\
\text { mushrooms }\end{array}$} & \multirow[t]{2}{*}{ Family } \\
\hline & & Color & Shape & & & & & \\
\hline GKVK1 & Soil & White & Umbonate & Free & Present & Tapering upwards & Macrolepiota globosa & Agaricacea \\
\hline GKVK2 & Wood & $\begin{array}{l}\text { Dark brown with } \\
\text { white margin }\end{array}$ & Irregular & Absent & Absent & Sessile & Ganoderma australe & Ganodermataceae \\
\hline GKVK3 & $\begin{array}{l}\text { Dry leaf } \\
\text { debris }\end{array}$ & Creamish white & Convex & Attached & Absent & Equal & Lepista sp. & Tricholomataceae \\
\hline GKVK4 & Soil & Greenish brown & Convex & Absent & Absent & Tapering upwards & Phlebopus portentosus & Boletinellaceae \\
\hline GKVK5 & Soil & Creamy white & Uplifted & Present & Absent & Tapering upwards & Termitomyces sp. & Lyophyllaceae \\
\hline GKVK6 & Soil & Yellowish brown & $\begin{array}{l}\text { Convex to } \\
\text { flat }\end{array}$ & Sinuate & Absent & Equal & Agrocybe pediades & Strophariaceae \\
\hline GKVK7 & $\begin{array}{l}\text { Dry leaf } \\
\text { debris }\end{array}$ & Orange & Convex & Free & Present & Tapering upwards & Leucoagaricus crystallifer & Agaricacea \\
\hline GKVK8 & $\begin{array}{l}\text { Dry leaf } \\
\text { debris }\end{array}$ & Cream & Petal like & Absent & Absent & Absent & Podoscypha petalodes & Meruliaceae \\
\hline GKVK9 & Soil & Creamy light brown & Plane & Free & Present & Equal & Agaricus sp. & Agaricacea \\
\hline GKVK10 & Soil & White & Convex & Present & Absent & Tapering upwards & Tricholoma giganteum & Tricholomataceae \\
\hline GKVK12 & Wood & Golden yellow & Funnel & Decurrent & Absent & Equal & Ompholotus olivascens & Omphalotaceae \\
\hline GKVK13 & Soil & Creamy white & Convex & Free & Present & Equal & Agaricus sp. & Agaricacea \\
\hline GKVK14 & Soil & $\begin{array}{l}\text { White and brown at } \\
\text { the center }\end{array}$ & Umbonate & Free & $\begin{array}{l}\text { Present } \\
\text { Absent }\end{array}$ & Equal & Macrolepiota dolochula & Agaricacea \\
\hline GKVK15 & $\begin{array}{l}\text { Wood } \\
(\text { Causuraina })\end{array}$ & Brown & Depressed & Decurrent & Absent & Equal & Panus conchatus & Polyporaceae \\
\hline GKVK16 & Soil & Orange & Convex & Free & Absent & Equal & Marasmius leveilleanus & Marasmiaceae \\
\hline GKVK17 & Soil & Light brown & Flat & Present & Absent & Equal & Polyporus arcularius & Polyporaceae \\
\hline GKVK18 & Soil & Cream with purple & Plane & Free & Present & Equal & Lepiota fuscovinacea & Agaricacea \\
\hline GKVK19 & $\begin{array}{l}\text { Dry leaf } \\
\text { debris }\end{array}$ & Brown & Plane & Sinuate & Absent & Equal & Agrocybe semiorbicularis & Strophariaceae \\
\hline GKVK20 & Humus & Light brown & Convex & Sinuate & Absent & Tapering upwards & Marasmius sp. & Marasmiaceae \\
\hline GKVK21 & Soil & Reddish brown & Kidney shape & Absent & Absent & Equal & Ganoderma lucidum & Ganodermataceae \\
\hline
\end{tabular}


Fig.1 Partial sequence length showing hundred percent homology to Macrolepiota globosa (707bp)

TTGTCGCTGGCTCCTTTGGAGCATGTGCACGCCTGTCTTGACTTCATTCATCCACCTG TGCACCACTTGTAGTCTTTGGGGGGTTTGTGAGAGAGAGAGTGGCTGACTTGTCGGG AATTCTCCCGGATGTGAGGACTGCAGTGTGAAAGCACGGCTCTCTTCTACCTGGCTA TGAACCCTTGCTCCCCCGAGGTCTATGTATTTATTCATACACCATGTAGCATGTTAAA GAATGTCTCAATGGGCCTTTGTGCCTATAAAATCATATACAACTTTCAGCAACGGAT CTCTTGGCTCTCGCATCGATGAAGAACGCAGCGAAATGCGATAAGTAATGTGAATTG CAGAATTCAGTGAATCATCGAATCTTTGAACGCACCTTGCGCTCCTTGGTATTCCGA GGAGCATGCCTGTTTGAGTGTCATTAAATTCTCAACTCCTCCAGCTTTTTGTTAAGTT GGCTTTGGAGCTTGGATGTGGAGGTTTGCTGGCCCTTGTATTGACTGGGTTCAGCTC CTCTGAAATACATTAGCGGAACCGTTTGCAATCCGCCACAGGTGTGATAATTATCTA CACCAGTGGGTTGCTCTCTGTGTTGTTCGGCTGCCAATCGTCTCTGCTTCAAAGAGAC AATTTTCTGAATGCTTGACCTCAAATCAGGTAGGACTACCCGCTGAACTTAAGCATA TCAAAAAGCCGGGAGAAGA

\begin{tabular}{|c|c|c|c|c|c|c|c|}
\hline \multicolumn{8}{|c|}{ Select: All None Selected:0 } \\
\hline \multicolumn{8}{|c|}{ î Alignments E Download $>$ GenBank Graphics Distance tree of results } \\
\hline & Description & $\begin{array}{l}\text { Max } \\
\text { score }\end{array}$ & $\begin{array}{l}\text { Total } \\
\text { score }\end{array}$ & $\begin{array}{l}\text { Query } \\
\text { cover }\end{array}$ & E value & Ident & Accession \\
\hline$\square$ & Mactolepiota globosa intental transcribed spacer 1, partial sequence, 5.65 ribosomal RNA yene, cc & 1204 & 1204 & $94 \%$ & 0.0 & $100 \%$ & AF482842.1 \\
\hline$\square$ & 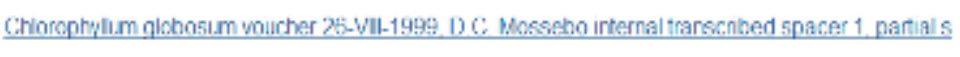 & 1204 & 1204 & $95 \%$ & 0.0 & $99 \%$ & AY243619.1 \\
\hline$\square$ & Chlorcphylum globosum woucher MFLU121815 internal transcribed spacer 1 , partial secuence, $5.8 \mathrm{~s}$ & 1166 & 1166 & $91 \%$ & 0.0 & $100 \%$ & $\underline{\mathrm{K}} \mathrm{J} 524553.1$ \\
\hline$\square$ & Chlorophyll.m mohthdites voucher MFI 2382837 intemal transcribed spacer 1, partial seguence; 5 \& & 1130 & 1130 & $100 \%$ & 0.0 & $96 \%$ & KP012712.1 \\
\hline$\square$ & Chorophylum mohbdites voucher MFLU121765 internal transcribed spacer 1, partial sequence: 5.8 & 1128 & 1128 & $97 \%$ & 0.0 & $97 \%$ & $\underline{K_{1} \mid 5>455.991}$ \\
\hline
\end{tabular}


Fig.2 Mushrooms of GKVK campus: GKVK1-Macrolepiota globosa, GKVK2- Ganoderma australe, GKVK3-Lepista sp., GKVK4-Phlebopus portentosus, GKVK5-Termitomyces sp., GKVK6-Agrocybe pediades, GKVK7-Leucoagaricus crystallifer, GKVK8-Podoscypha petalodes, GKVK9-Agaricus Sp, GKVK10-Tricholoma giganteum, GKVK11-Coprinellus disseminates, GKVK12-Omphalotus olivascens, GKVK13-Agaricus sp, GKVK14-Macrolepiota dolichaula, GKVK15-Panus conchatus, GKVK16-Marasmius leveilleanus, GKVK17-Polyporus arcularius, GKVK18-Lepiota fuscovinacea, GKVK19-Agrocybe semiorbicularis, GKVK20-Marasmius sp. and GKVK21-Ganoderma lucidum.
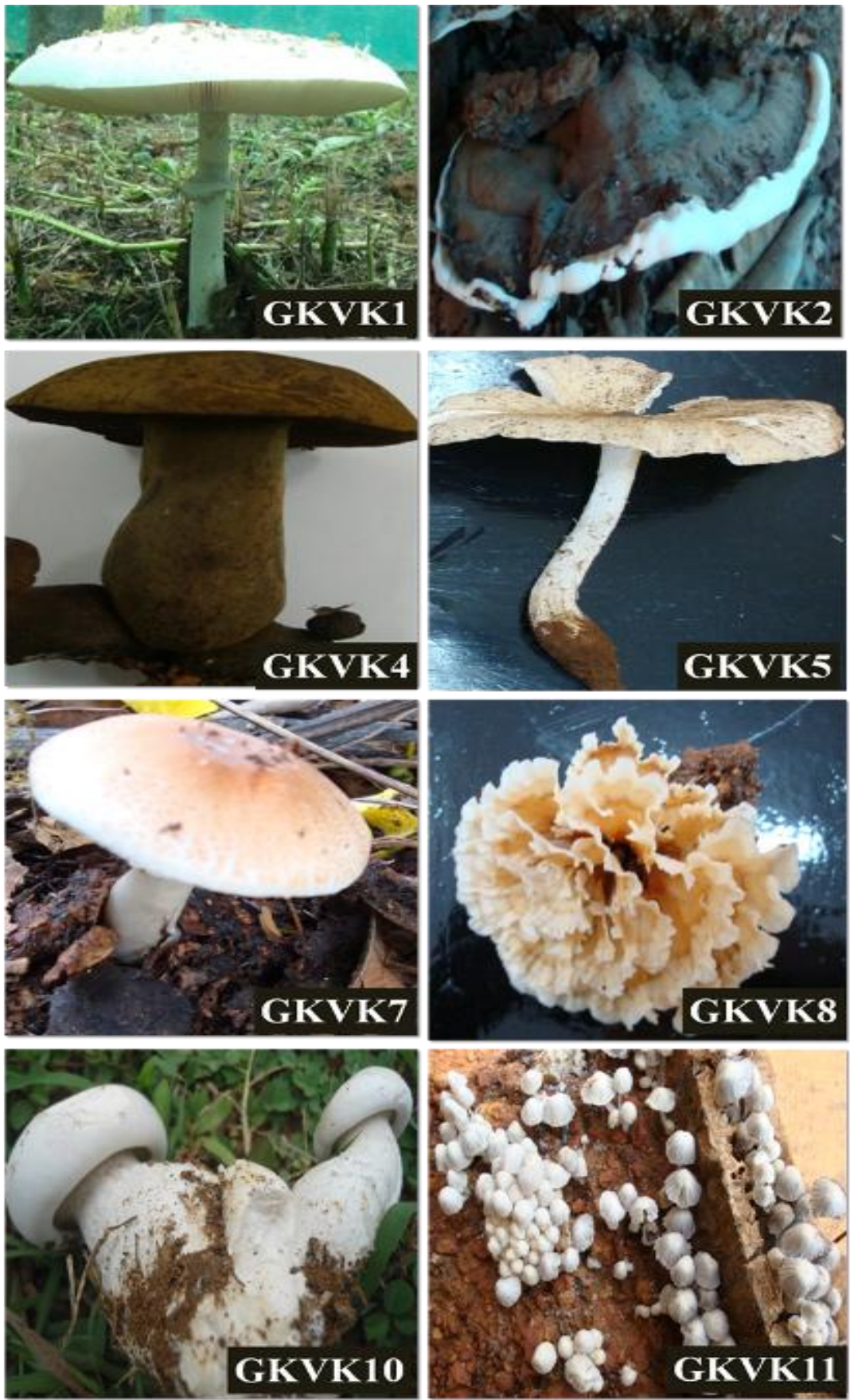
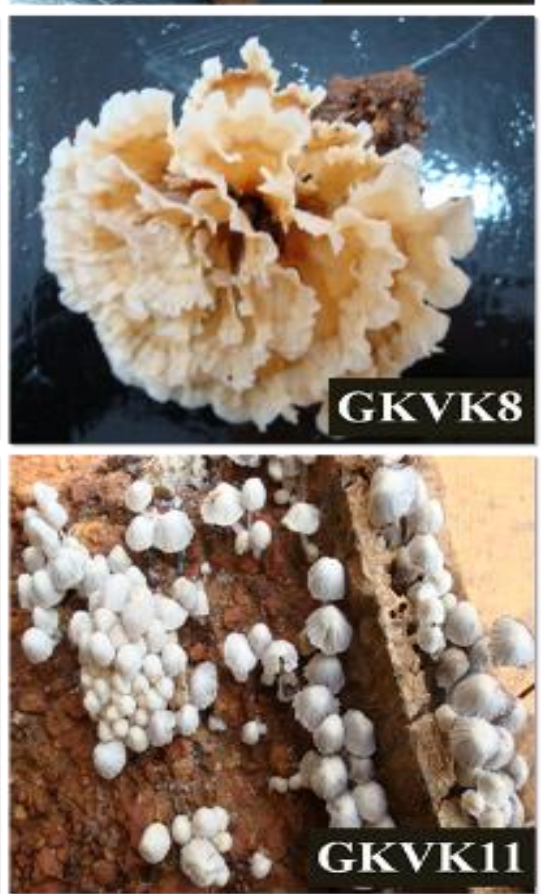
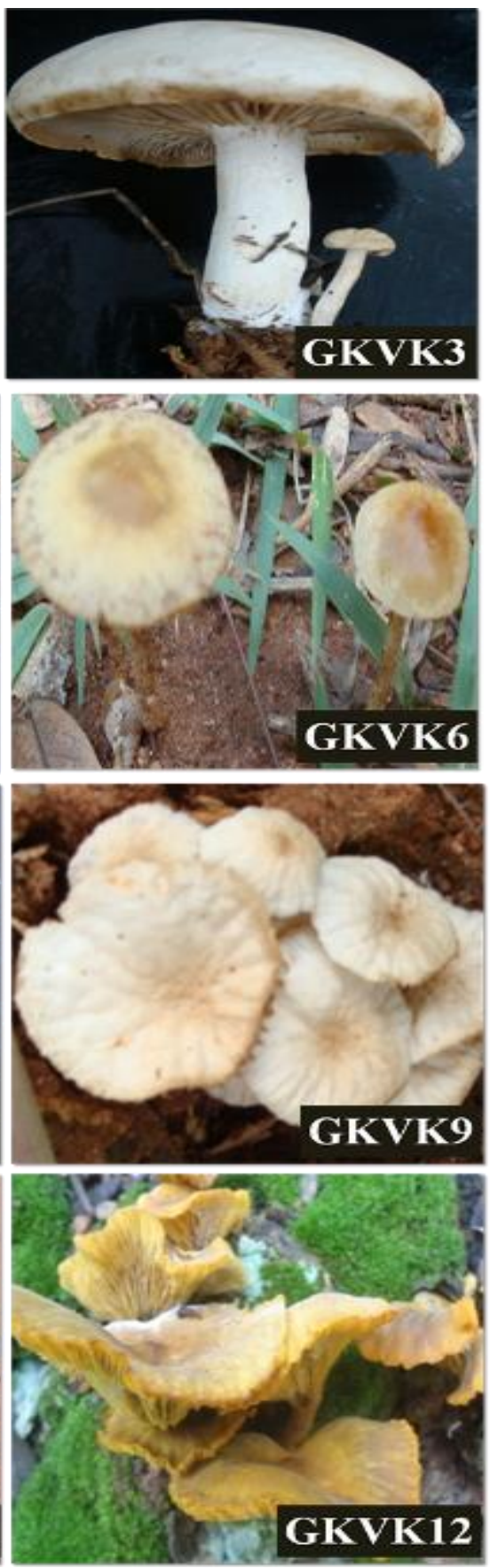

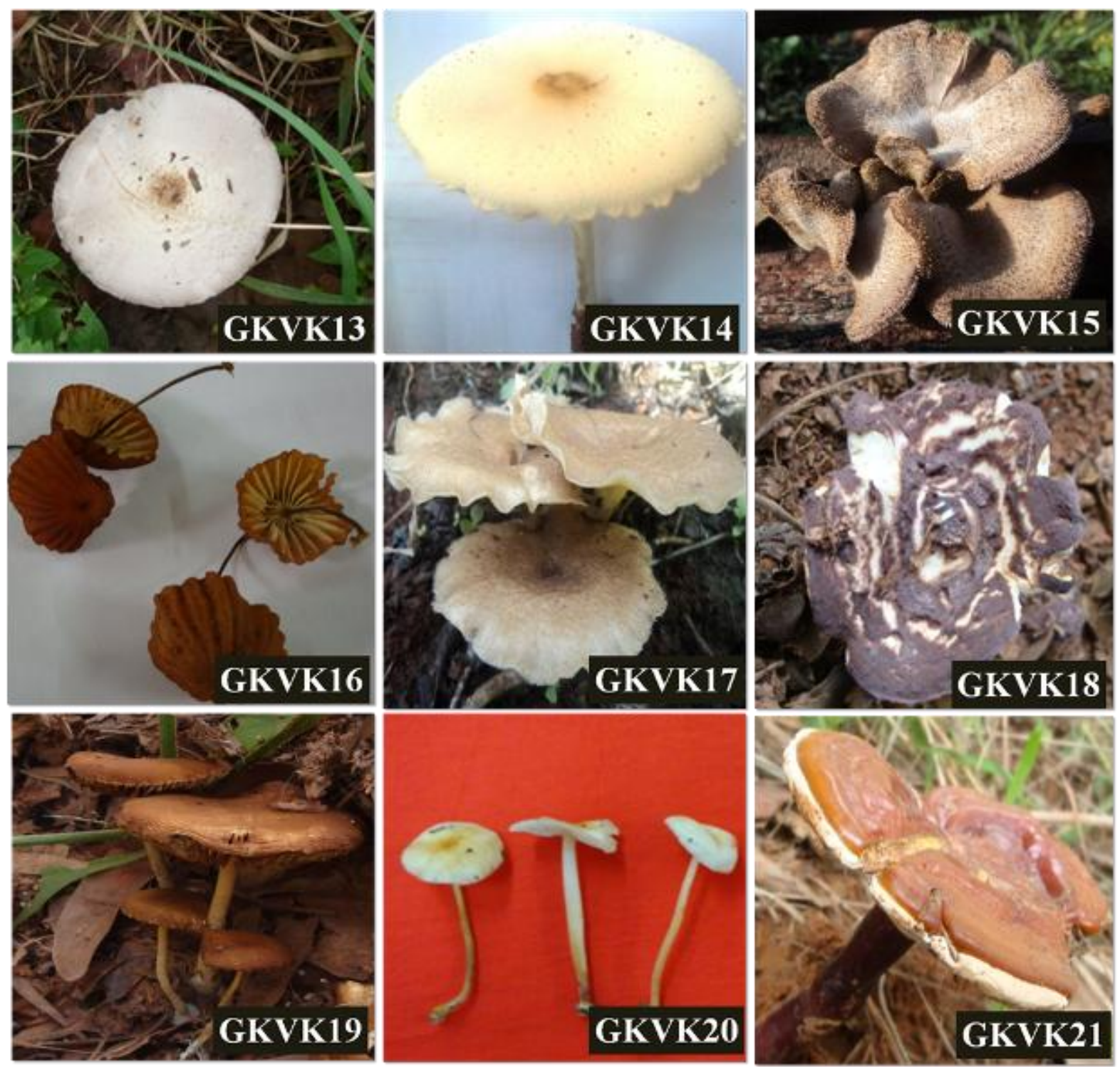

Out of twenty one mushrooms collected, eleven species (GKVK-5,6,7,8,9,13, $15,17,18,19$ and 21) were documented from Botanical garden of the campus. Richness of the mushroom species in the botanical garden is due to undisturbed soil condition and rich organic matter content of the soil. Whereas in the other locations, such as FTI block (GKVK-3), NSP block (GKVK-14), K block (GKVK-10,16 and 20), near South and North block blocks (GKVK-2, 4, 11and 12) number of mushroom flora decreased due to human intervention. However, richness of the species is more compared abundance as richness of the species depends on characteristics of the habitat and ecosystems in which they establish. Abundance of mushroom species belongs to Agrocybe and Leucoagaricus have been reported from Western ghats of Kerala (Arunkumar and Manimohan, 2009). Similarly, Farook et al., (2013) reported 616 species of gilled mushrooms belonging in 112 genera and 50 orders from Kerala state. Ranadive et al., (2013) collected 20 species of Aphyllophorales from 10 host plants growing in 15 different localities of the Western Ghats of Pune districts of Maharashtra state, India. In the present study we report 21 species of 
mushrooms belonging to 11 families envisaging the mushroom diversity of the campus (Table 1). Out of 21 species, the Termitomyces sp., Tricholoma gigantenum, Polyporus arcularius and Coprinellus disseminates are belong to edible mushrooms and two species viz., Ganoderma lucidum and Ganoderma australe are medicinally important mushrooms. Remaining fifteen mushrooms were regarded as non-edible mushroom or poisonous or edibility is not known.

\section{References}

Aroroa, D., Mushroom demystified: A comprehensive guide to the fleshy fungi. Ten Speed Press, Crown Publishing Group, New York, 1986; pp: 8-20.

Arun Kumar T.K. and Manimohan, P. 2009. The genera Leucoagaricus and Leucocoprinus (Agaricales, Basidiomycota) in Kerala State, India. Mycotaxon., 108: 385-428.

Bakshi, B.K. 1971. Genus Ganoderma In: Indian Polyporaceae. Indian Council of Agricultural Research, New Delhi, pp.58-62.

Brown, A.J. and Casselton, L.A. 2001. Mating in mushrooms: increasing the chances but prolonging the affair. Trends Genet., 17(7): 393-400.
Chang, S.T. and Miles, P.G. 2004. The nutritional attributes of edible mushrooms. In Mushrooms: Cultivation, Nutritional value, Medicinal effect and environmental impact. Boca Raton, FL: CRC Press, London pp.27-38.

Doyle, J. and Doyle, J.L. 1987. Genomic plant DNA preparation from fresh tissue-CTAB method. Phytochem. Bull., 19(11): 11-15.

Farook, A., Khan, S.S. and Manimohan, P. 2013. A checklist of agarics (gilled mushrooms) of Kerala State, India. Mycosphere, 4(1): pp.97-131.

Hall, I.R., Yun, W. and Amicucci, A. 2013. Cultivation of edible ectomycorrhizal mushrooms. Trends Biotechnol., 21(10): 433-438.

Mahajan, P.V., Oliveira, F.A.R. and Macedo, I. 2008. Effect of temperature and humidity on the transpiration rate of the whole mushrooms. J. Food Eng., 84(2): 281-288.

Rajaratnam, S. and Thiagarajan, T. Molecular 2012. characterization of wild mushroom. Eur. J. Expl Biol., 2(2): 369-373.

Ranadive, K.R., Jite, P.K., Ranade, V.D. and Vaidya, J.G. 2013. Flora of Aphyllophorales from Pune DistrictPart I. J.. New Biol. Rep., 2(3): 188-227.

\section{How to cite this article:}

Sandhya, M.C., K.N. Prabhu and Earanna, N. 2017. Mushroom Diversity of the Gandhi Krishi Vigyana Kendra (GKVK) Campus, University of Agricultural Sciences, Bangalore, Karnataka (India). Int.J.Curr.Microbiol.App.Sci. 6(4): 2279-2286.

doi: https://doi.org/10.20546/ijcmas.2017.604.265 